\title{
Treatment of superficial mycoses: review - part II
} Atualização terapêutica das micoses superficiais: artigo de revisão parte II

\author{
Maria Fernanda Reis Gavazzoni Dias ${ }^{1}$ \\ Maria Victória Pinto Quaresma-Santos ${ }^{2}$ \\ Regina Casz Schechtman ${ }^{4}$
}

\author{
Fred Bernardes-Filho ${ }^{2}$ \\ Adriana Gutstein da Fonseca Amorim ${ }^{3}$ \\ David Rubem Azulay ${ }^{5}$
}

\begin{abstract}
Superficial fungal infections of the hair, skin and nails are a major cause of morbidity in the world. Choosing the right treatment is not always simple because of the possibility of drug interactions and side effects. The first part of the article discusses the main treatments for superficial mycoses - keratophytoses, dermatophytosis, candidiasis, with a practical approach to the most commonly-used topical and systemic drugs , referring also to their dosage and duration of use. Promising new, antifungal therapeutic alternatives are also highlighted, as well as available options on the Brazilian and world markets.

Keywords: Antifungal agents; Dermatomycoses; Mycoses; Therapeutics; Tinea; Yeasts

Resumo: As infecções fúngicas superficiais dos cabelos, pele e unhas representam uma causa importante de morbidade no mundo. O tratamento nem sempre é simples, havendo dificuldade na escolha dos esquemas terapêuticos disponíveis na literatura, assim como suas possíveis interações medicamentosas e efeitos colaterais. A segunda parte do trabalho aborda os principais esquemas terapêuticos das micoses superficiais - ceratofitoses, dermatofitoses, candidíase -, possibilitando a consulta prática das drogas tópicas e sistêmicas mais utilizadas, sua dosagem e tempo de utilização. Novas possibilidades terapêuticas antifúngicas também são ressaltadas, assim como as apresentações disponíveis no mercado brasileiro e mundial.

Palavras-chave: Antifúngicos; Dermatomicoses; Leveduras; Micoses; Terapêutica; Tinha
\end{abstract}

\section{ANTIFUNGAL DRUGS}

These are antibiotic or chemotherapeutic substances that act directly or indirectly on fungi and thus are of therapeutic use in mycoses. ${ }^{1,2}$ At the end of the 60 's and $70^{\prime} \mathrm{s}$, the discovery of imidazole derivatives with antifungal activity was an important milestone in the treatment of superficial and deep mycoses, due to their high efficacy and low toxicity, as well as immunomodulatory activity. ${ }^{1,3}$ In the last two decades several new antifungal agents with better absorption and effectiveness were discovered. ${ }^{2,4}$
The efficacy of topical agents in superficial mycoses depends not only on the type of lesion and the actual mechanism of action of the drug, but also on the viscosity, hydrophobicity and acidity of the formulation. Regardless of the type of formulation, topical agents penetration in hyperkeratotic lesions is often precarious., ${ }^{3,4-6}$ Products used for cutaneous application tend to be manufactured in creams or solutions. Ointments are cumbersome and overly occlusive to be used in macerated or fissured intertriginous lesions. The use of powders, applied either in

Received on 27.07.2012.

Approved by the Advisory Board and accepted for publication on 11.12.2012.

* Work performed at Professor Rubem David Azulay Dermatology Institute at Santa Casa da Misericórdia do Rio de Janeiro (IDPRDA - SCMRJ) - Rio de Janeiro (RJ), Brazil.

Financial Support: None

Conflict of Interest: None

MD, PhD, Professor of the Post-Graduation program at Prof. Rubem David Azulay Dermatology Institute at Santa Casa da Misericórdia do Rio de Janeiro (IDPRDA - SCMRJ) - Rio de Janeiro (RJ), Brazil.

MD, Post-graduation in course at Prof. Rubem David Azulay Dermatology Institute at Santa Casa da Misericórdia do Rio de Janeiro (IDPRDA - SCMRJ) - Rio de Janeiro (RJ), Brazil.

MD, Dermatologist - Private practice - Rio de Janeiro (RJ), Brazil.

MD, PhD in Dermatology at London University. Coordinator of the Dermatology post-graduation program and chief of the mycology sector at Prof. Rubem David Azulay Dermatology Institute at Santa Casa da Misericórdia do Rio de Janeiro (IDPRDA - SCMRJ) - Rio de Janeiro (RJ), Brazil.

MD, MSc, Chief of the Dermatology Service at Prof. Rubem David Azulay Dermatology Institute at Santa Casa da Misericórdia do Rio de Janeiro (IDPRDA SCMRJ) - Rio de Janeiro (RJ), Brazil. Chair Professor of the Post-graduation Program at Rio de Janeiro Pontifical Catholic University (PUC-RJ). Professor at Souza Marques Foundation and Rio de Janeiro Federal University (UFRJ) - Rio de Janeiro (RJ), Brazil. 
sprays or aerosol form, is limited in large part to the feet area and lesions in moist intertriginous areas. Cutaneous formulations are not suitable for oral, vaginal or ocular use., ${ }^{3,7-10}$

Antifungal drugs can be categorized into several classes, as shown in table 1 .

\section{POLYENES}

These antifungal drugs were first described in 1950, and their production occurs through fermentation of Streptomyces species. They have a higher affinity for the ergosterol in fungal cell membranes than for cholesterol in human cell membranes, which facilitates the destruction of fungi. ${ }^{1,2,3,10}$

These drugs are indicated for the treatment of superficial and systemic fungal infections but they do not act on dermatophytes. ${ }^{1,2,3,10,11}$

\section{NYSTATIN} tion. . $10,12-14^{1}$

It is both a fungicide and a fungistatic medica-

It is effective and has exclusive topical use in the treatment of mucocutaneous candidiasis, since it is practically unabsorbed by the gastrointestinal tract (GIT). It is ineffective in dermatophytosis.

Commercial presentation forms may be cream, ointment, oral suspension 100,000 IU / $\mathrm{ml}$ or coated pills $(500,000 \mathrm{M})$.

There are also combinations of nystatin with antimicrobial or corticosteroids

Category B in pregnancy.

Dosage:

Cutaneous candidiasis: 2-3 times / day;

Vaginal: 1-2 times / day;

TABLE 1: Antifungal drugs classification

\section{CLASS}

Polienes

Azoles

Allylamines

Equinocandines

Hydroxypyridone

Morpholine Derivatives

Other

New

\section{DRUGS}

Nystatin (cream, ointment and oral suspension) Amphotericin B*

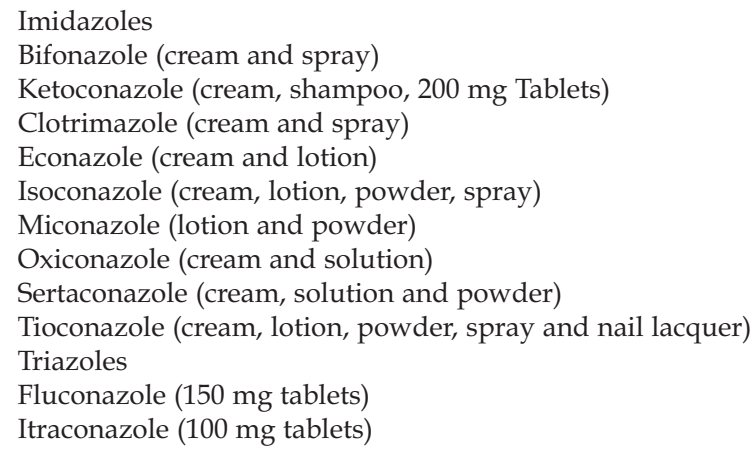

Naftifine

Terbinafine (cream, spray, 125 or $250 \mathrm{mg}$ tablets)

Butenafine

\section{Caspofungin* \\ Micafungin*}

Ciclopirox olamine (cream, solution, nail lacquer)

Amorolfine (cream and nail lacquer)

Griseofulvin (500 mg tablets)

Rilopirox: ciclopirox olamine derivative. Indications: candidiasis, pityriasis versicolor and seborrheic dermatitis

Lanoconazole: use in dermatophytoses and candidiasis

NND-502*: lanoconazole analogue. Used in tinea pedis treatment.

Eberconazole: indicated in dermatophytoses and triazole resistant mycoses (Candida kruzei and C. glabrata).

Voriconazole: fluconazole derivative.*

Terconazole

Posaconazole*

Ravuconazole*

\footnotetext{
* Indicated for the treatment of systemic mycoses
} 
Oral mucosa / esophagus: 1-2 $\mathrm{ml}$ oral suspension, 4 times / day; or coated pills, 1 or even 2 pills each $8 \mathrm{~h}$, also indicated in recurrent perineal infections.

Drug Interactions: unknown

Adverse Events: contact dermatitis (most common), Stevens-Johnson syndrome (rare), pruritus, dyspepsia, nausea, vomiting, diarrhea, fixed pigmented erythema, tongue edema, tachycardia, myalgia, and bronchospasm.

\section{AMPHOTERICIN B}

It can be fungistatic or fungicidal depending on drug concentration and fungal sensitivity. ${ }^{1,2,10,13-15}$ Among the superficial mycoses, it is effective in candidiasis and was also recently been proposed for the topical treatment of onychomycosis caused by nondermatophyte fungi.

It is a broad-spectrum antifungal drug for intravenous use, not indicated in uncomplicated superficial mycoses.

Category B in pregnancy.

Commercial presentation: $50 \mathrm{mg}$ vials.

The usual therapeutic dose of amphotericin B is $0.5-0.6 \mathrm{mg} / \mathrm{kg}$ administered in 5\% dextrose, for more than 4 hours

It is commercially available as lotion, cream, and ointment; all such preparations should contain 3\% of amphotericin B and be applied to the lesion 2-4 x / day

Drug Interactions: adefovir, aminoglycosides, astemizole, cephalothin, cidofovir, cyclosporine, digoxin, ethoxzolamide, fluconazole, flucytosine, ganciclovir griseofulvin, hydrocortisone, itraconazole, ketoconazole, pentamidine, probenecid, sulpiride, terbinafine, triamcinolone.

Adverse Events: multiform erythema, fixed pigmented rash, itching, red man syndrome, urticaria, alopecia, arrhythmia, hypotension, hypertension, thrombophlebitis, anorexia, chills, delirium, fever, headache, tachypnea, nausea and vomiting.

\section{AZOLES}

Azoles can be either imidazoles (with two nitrogen atoms in the azole ring) or triazoles (with 3 nitrogen atoms in the azole ring). . $-3,10-14,16-19$ They are fungistatic, except in high concentrations, when they can also be fungicides. Azoles are able of inhibiting the demethylation of sterol's carbon-14 in fungal wall cells and consequently inhibit the normal ergosterol biosynthesis, modifying its biochemical composition, and leading to inhibition of fungal growth and replication. Triazoles such as fluconazole, itraconazole, voriconazole, posaconazole and ravuconazole are used for systemic treatments.

Both forms of azole share the same antifungal spectrum and the same mechanism of action. Systemic triazoles are more slowly metabolized and exert less effect on human sterol synthesis than imidazoles.

\section{IMIDAZOLES}

\section{CLOTRIMAZOLE:}

It was the first imidazole derivative.

Presentation: cream, spray, lotion and $1 \%$ solution

Category B in pregnancy.

The absorption rate of clotrimazole is less than $0.5 \%$ following application to intact skin.

Skin applications are made $2 \mathrm{x} /$ day

Indication: Dermatophytosis (Trichophyton, Epidermophyton and Microsporum species), tinea versicolor and oral or mucocutaneous candidiasis.

It cures dermatophyte infections in $60-100 \%$ of cases. Cure rates in cutaneous candidiasis reach $80-100 \%$. Drug Interactions: betamethasone, cyproterone.

Adverse Events: erythema, pruritus, rash, and dysgeusia.

\section{ECONAZOLE}

It interrupts the conversion of lanosterol to ergosterol thus arresting fungal growth.

This drug is available as water miscible cream $(1 \%)$ and lotion.

Category $\mathrm{C}$ in pregnancy.

Indications: dermatophytosis (tinea pedis, tinea cruris and tinea corporis), cutaneous candidiasis and tinea versicolor.

Interactions: acenocoumarol, preservatives, contraceptive diaphragms, imidazole, warfarin.

Adverse Events: contact dermatitis, erythema, burning and itching.

\section{KETOCONAZOLE}

First broad-spectrum antifungal drug administered orally.

Topically, it is indicated in all superficial mycoses and seborrheic dermatitis.

Oral treatment should be reserved for cases of extensive, severe or recalcitrant disease or if there was a previous failure with topical treatment. ${ }^{1}$ Oral absorption is better when administered with acidic beverages. In dermatophytosis, length of treatment keeps certain parallels with that of griseofulvin. Cutaneous, mucosal or mucocutaneous candidiasis should be treated for 10-20 days. Children over 2 years: 3-6 mg / $\mathrm{kg} /$ day. In tinea versicolor its use is off-label, the recommended dose is $200 \mathrm{mg} / \mathrm{d}$ for 10 days and it may include topical treatment with selenium sulfide shampoo, with a recurrence rate at 2 years of $60-90 \%$. $^{7}$

Commercial presentation: $200 \mathrm{mg}$ tablets, cream, shampoo. 


\section{Category $\mathrm{C}$ in pregnancy.}

Drug Interactions: alcohol, alitretinoin, alprazolam, amphotericin B, anticoagulants, atazanavir, benzodiazepines, cimetidine, clopidogrel, colchicine, cyclosporine, erythromycin, imatinib, lopinavir, methylprednisolone, midazolam, nevirapine, omeprazole, pimecrolimus, prednisolone, prednisone, rifampin, ritonavir, saquinavir, sildenafil, simvastatin, tacrolimus, tramadol, triamcinolone, vardenafil, vemurafenib.

Adverse Events: itching, burning, stinging and contact dermatitis were described with the use of topical medication. With oral medication: epigastric pain, vomiting, nausea, antabuse effect, skin rash, drowsiness, hemolytic anemia, impotence, decreased libido, and gynecomastia (due to the anti-androgenic action at the adrenal and testis levels), hepatotoxicity.

\section{MICONAZOLE}

Indicated for all superficial mycoses.

Commercial presentations: lotion, oral gel and powder, ointment, cream, solution, spray, dermatologic powder or lotion. To avoid maceration, only the lotion formulation should be applied to intertriginous areas.

Category B in pregnancy.

Drug Interactions: anisindione, anticoagulants, astemizole, clopidogrel, dicumarol, gliclazide, simvastatin, thioridazine, tolvaptan, vinblastine, vincristine, warfarin

Adverse Events: irritation, burning, maceration, allergic contact dermatitis, and pruritus.

\section{OXICONAZOLE}

Indicated for all superficial mycoses.

Commercial presentations: cream and lotion solution.

Category B in pregnancy.

Drug Interactions: unknown

Adverse Events: itching, irritation, burning, erythema, papules, fissure, maceration, and allergic contact dermatitis.

OTHER: Isoconazole, Bifonazole 1\%, Sertaconazole, Tioconazole, Butoconazole, Sulconazole

\section{TRIAZOLES}

The concomitant use of triazoles with some medications may increase their plasma concentrations, which contraindicates the association with astemizole, terfenadine, midazolam, lovastatin, simvastatin, and atorvastatin. Association should also be avoided with rifampicin, rifabutin, and protease inhibitors. Triazoles should be used with caution when associated to: digoxin, cyclosporine, methylprednisolone, warfarin, phenytoin, oral hypoglycemic agents, quinidine, tacrolimus, calcium channel blockers, carbamazepine, $\mathrm{H}_{2}$-blockers and antihistamines.

\section{ITRACONAZOLE}

It is a synthetic, fungistatic triazole, that inhibits cytochrome P 450 enzyme, hindering the conversion of lanosterol to ergosterol and interrupting fungal cell growth and division. ${ }^{1,2,3,10,12-14,16,20,21-25}$ Best absorbed after a meal, this drug is metabolized by the liver and eliminated through the kidneys. Itraconazole presents far fewer side effects than ketoconazole, especially at the hepatic level. Contraindicated in patients with congestive heart failure.

Itraconazole is metabolized in the liver, primarily by cytochrome CYP3A4 isoenzymatic system that inhibits the metabolism of other drugs by CYP3A4.

Advanced hepatic diseases increase plasma concentration of itraconazole, while azotemia and hemodialysis have no effect on it. Intravenous administration of itraconazole is contraindicated in patients with creatinine clearance below $30 \mathrm{~mL} / \mathrm{min}$. Parenteral route is most appropriate for patients that do not tolerate oral formulations or are unable to absorb it due to reduction of gastric acid levels.

Indication: dermatophytosis (for onychomycosis in toenails use $200 \mathrm{mg} / \mathrm{d}$ continuously for 12 weeks or pulse therapy with $200 \mathrm{mg}$ twice daily for 1 week per month with 3 pulses) and yeast infections. Off label use in the treatment of tinea capitis, corporis, pedis, manum, cruris, pityriasis versicolor $(100 \mathrm{mg} 2$ times / day for 5 days), onychomycosis caused by Candida spp or non-dermatophyte fungi and onychomycosis in children.

Commercial presentation: $100 \mathrm{mg}$ capsules.

Category $\mathrm{C}$ in pregnancy.

Drug Interactions (Chart 1): Rifampicin reduces the plasma level of itraconazole and diphenylhydantoin increases it. Alprazolam, amphotericin B, atazanavir, atorvastatin, calcium channel blocker, carbamazepine, cimetidine, clarithromycin, clopidogrel, colchicine, corticosteroids, cyclophosphamide, cyclosporine, dexamethasone, diazepam, digoxin, efavirenz, ergotamine, erythromycin, fentanyl, haloperidol, imatinib, indinavir, isoniazid, lopinavir, methylprednisolone, midazolam, omeprazole, oral hypoglycemic agents, phenytoin, pimecrolimus, prednisolone, prednisone, rifampin, ritonavir, saquinavir, sildenafil, simvastatin, vardenafil, warfarin.

Adverse effects: headache, nausea, abdominal pain, diarrhea, dyspepsia, gastritis, hepatitis, urticaria, rash, Stevens Johnson syndrome, dizziness, hypertension, hypokalemia, hypertriglyceridemia and rarely neutropenia and liver failure. 
Photosensitivity, phototoxicity, alopecia, cardiovascular, central nervous, musculoskeletal, gastrointestinal, and respiratory systems symptoms may also occur.

\section{FLUCONAZOLE}

It is a water-soluble substance with high and fast oral absorption, which is not influenced by food or gastric $\mathrm{pH} .1-5,9-14,16,20-25 \quad$ Fluconazole inhibits cytochrome $\mathrm{P} 450$.

Indications: superficial mycoses caused by Candida species. Used off-label for the treatment of onychomycosis, dermatophytosis (tinea pedis / corporis - $150 \mathrm{mg}$ / week for 2-3 weeks, and tinea capitis / cruris - the same dose for 4-6 weeks), chronic mucocutaneous candidiasis and pityriasis versicolor $(400 \mathrm{mg}$ single dose) ${ }^{1,2}$ The dose for children over 6 months is 3-6 mg / kg / week. ${ }^{6}$

Commercial presentation: $150 \mathrm{mg}$ capsules and solution for intravenous infusion.

Category $\mathrm{C}$ in pregnancy.

Drug interactions: alprazolam, amphotericin B, anticoagulants, atorvastatin, clopidogrel, erythromycin, midazolam, nevirapine, phenobarbital, phenytoin, pimecrolimus, propranolol, sulfonylurea, triamcinolone, warfarin, zidovudine.

Adverse events: headache, nausea, abdominal pain, diarrhea, dyspepsia, dizziness, change in palatability, QT prolongation with or without arrhythmia (Torsade de Pointes) and rarely anaphylaxis. Acneiform eruption, anaphylaxis / anaphylactoid reaction (in AIDS), fixed pigmented rash, neutropenia, eye hemorrhage and teratogenicity may also occur.

\section{Fluconazole - avoid use with:}

Alprazolam - increased plasma level - sedation

Amphotericin B - increases the plasma level of fluconazole
Astemizole - increases the risk of serious arrhythmias

Carbamazepine - decreases the efficacy of fluconazole

Cimetidine - decreases the efficacy of fluconazole

Cisapride - increases the risk of serious arrhythmias

Clarithromycin - increased plasma level

Chlorpropamide - risk of hypoglycemia

Estradiol - possibly decreased plasma level

Phenytoin - increased plasma level - toxicity and reduced efficacy

Glyburide - hypoglycemia may occur

Glipizide - hypoglycemia may occur

Hydrochlorothiazide - may increase the plasma levels of fluconazole

Levonorgestrel - possibly decreased plasma level

Loratadine - plasma levels may increase

Midazolam - plasma levels may increase

Pimozide - increased plasma level - arrhythmias

Retinoid - plasma levels may increase

Rifabutin - decreased efficacy of fluconazole, may

increase the plasma levels - bilateral uveitis

Ritonavir - plasma levels may increase

Tacrolimus - nephrotoxicity

Theophylline injection - increased plasma level

Terfenadine - risk of arrhythmias

Thiazide - increases the plasma level of fluconazole Tolbutamide - hypoglycemia may occur

Triazolam - increased plasma level

Warfarin - increased plasma level - bleeding

Zidovudine - increased plasma level

\section{ALLYLAMINES TERBINAFINE}

This drug acts by inhibiting the squalene epoxidase enzyme in fungal cell membranes, leading to deficiency in ergosterol and accumulation of intracellular

CHART 1: Interactions of itraconazole with other drugs

$\begin{array}{lll}\begin{array}{l}\text { Drugs with increased plasma con- } \\ \text { centration }\end{array} & \begin{array}{l}\text { Drugs that reduce itraconazole } \\ \text { plasma concentration }\end{array} & \begin{array}{l}\text { Drugs that increase itra- } \\ \text { conazole plasma con- } \\ \text { centration }\end{array}\end{array}$

Vinca alkaloids, alfentanyl, alprazolam, astemizole, atorvastatin calcium channel blockers, bromperidol, buspirone, cerivastatin, cyclosporine, cisapride, delavirdine, diazepam, digoxin, phenytoin, indinavir, loratadine, lovastatin, midazolam, pimozide, quinidine, ritonavir, saquinavir, sildenafil, simvastatin, sulfonylureas, tacrolimus, triazolam, warfarin, verapamil
$\mathrm{H} 2$ receptor blockers, proton pump blockers, simultaneous antacids, simultaneous didanosine (buffered), carbamazepine, phenobarbital, phenytoin, rifampin, rifabutin, isoniazid, nevirapine
Clarithromycin, indinavir, ritonavir 
squalene. ${ }^{1,2,3,11-14,16,20-25}$ It is metabolized by some of cytochrome P450 system's isoenzymes, particularly CYP2D6, which explains its low potential for drug interactions. It is fungicidal against dermatophytes, and can be fungicidal or fungistatic against yeasts, depending on the species. The drug availability is not altered by food; plasma concentration peak occurs in $2 \mathrm{~h}$, binding strongly to plasma proteins (99\%). The half-life is 17 hours. It has hepatic metabolism and the inactive metabolites are eliminated in urine, so patients with renal or hepatic impairment should have their dosage reduced.

It is not recommended for patients with hepatic impairment or pronounced azotemia, because plasma levels can increase up to unpredictable amounts.

Indications: it is fungicidal against dermatophytes; against yeasts it can be either fungicidal or fungistatic, depending on the species. Topical presentation is effective on tinea versicolor, unlike pills.

Commercial presentation: $125 \mathrm{mg}$ or $250 \mathrm{mg}$ tablets and $1 \%$ cream

Children over $12 \mathrm{~kg}: 62.5 \mathrm{mg} / \mathrm{d}$;

Children 20-40 kg: $125 \mathrm{mg} / \mathrm{d}$;

Children over $40 \mathrm{~kg}$ and adults: $250 \mathrm{mg} / \mathrm{d}$.

Terbinafine cream is applied $2 \times$ / day

Length of treatment: 4-6 weeks in tinea pedis, and from 3 to 6 months or longer in onychomycosis.

Risk B in pregnancy.

Drug Interactions: amitriptyline, carbamazepine rarely interacts with other drugs, but its metabolism can be accelerated by rifampicin and delayed by cimetidine.

Adverse events: local, gastrointestinal or cutaneous irritations, change in palatability, rash, urticaria and rarely hepatotoxicity. Drug-induced lupus erythematosus, lichenoid eruption, photosensitivity, pityriasis rosea, pruritus, Sjogren's syndrome, StevensJohnson syndrome, toxic epidermal necrolysis, alopecia, onychocryptosis.

\section{Terbinafine - avoid use with:}

Caffeine - increases plasmatic levels

Cyclosporine - reduces plasmatic levels

Cimetidine - increases plasmatic levels of terbinafine

Rifampicin - reduces terbinafine's efficacy

\section{BENZYLAMINES}

\section{BUTENAFINE}

Acts by inhibiting squalene epoxidase in the fungal cell membrane, leading to a deficiency of ergosterol and accumulation of intracellular squalene. . $^{-4,11-14,16}$

Indications: dermatophytosis, candidiasis, and pityriasis versicolor.
Commercial presentation: Cream

Adverse events: burning, itching, contact dermatitis, and erythema.

\section{EQUINOCANDINES}

Used as therapeutic options for invasive fungal infection. ${ }^{11,13,14,16}$

\section{CASPOFUNGIN \\ MICAFUNGIN}

Category $\mathrm{C}$ in pregnancy. sirolimus

Drug Interactions: itraconazole, nifedipine,

Adverse Events: anaphylaxis / anaphylactoid reaction, hyperhidrosis, urticaria, pruritus, epistaxis, hypotension, hypertension, dyspnea, arthralgia, central nervous system or gastrointestinal symptoms.

\section{HYDROXYPYRIDONE \\ CICLOPIROX}

It has anti-inflammatory properties by inhibition of cyclooxygenase, 5-lipoxygenase, prostaglandins and leukotrienes. Inhibits the uptake of essential components and undermines the integrity of fungal cell membrane. . $11,13,14,16,26^{-1}$

Indications: dermatophytosis, candidiasis, pityriasis versicolor, seborrheic dermatitis

Presentation: cream, solution, nail lacquer

Category B in pregnancy.

Drug Interactions: unknown

Adverse events: irritation, burning, pain, erythema, pruritus, nail pigmentation, and onychocryptosis.

\section{MORPHOLINE DERIVATIVES AMOROLFINE}

Acts mainly by modifying the membrane sterol biosynthesis, reducing the ergosterol content and leading to an accumulation of abnormal sterols. ${ }^{11,13,14,16,21}$

Information: effective in all superficial mycoses. The cream is used $1 \mathrm{x} / \mathrm{d}$ until clinical cure and, after that, maintained for several days. The length of treatment must always be greater than 2 weeks, and in tinea pedis, 4-8 weeks. The nail lacquer formulation is used in onychomycosis, $1 \mathrm{x} /$ week, with an average duration of treatment of 4-6 months for hand affections and 6-12 months for toes. It can be used $2 x /$ month for 6 months to prevent recurrences in chronic onychomycosis.

\section{OTHER}

Commercial presentation: cream or nail lacquer.

\section{GRISEOFULVIN}

It is a fungistatic derived from the metabolism of Penicillium griseofulvum. ${ }^{1-4,11-14,16,17,24}$ It has exclusive action against dermatophytes and acts by interfering with DNA synthesis. Griseofulvin is better absorbed in the 
form of microcrystals and in the presence of fat. It is metabolized in the liver and eliminated by the kidneys, reaching the skin surface possibly through sweating.

Indications: dermatophytosis (treatment of choice for microsporic tinea). Dosage for children is between 15-20 mg / kg / day for 6-8 weeks and for adults: 1 or 2 tablets after a meal.

The recommended daily dose of griseofulvin is $5-15 \mathrm{mg} / \mathrm{kg}$ for children and $500 \mathrm{mg}-1 \mathrm{~g}$ for adults. Doses of 1.5-2.0 g / day may be required for short periods in the treatment of serious or extensive infections. The best results are obtained when the daily dose is fractionated and administered every 6 hours, although the drug is often administered $2 \times$ / day. Treatment should be continued until the infected tissue is replaced with normal hair, skin or nails, requiring 1 month for scalp and hair dermatophytoses, 6-9 months for fingernails and at least 1 year for toenails. Commercial presentation: $500 \mathrm{mg}$ tablets.

Category $\mathrm{C}$ in pregnancy.

Drug Interactions: Alcohol, levonorgestrel, liraglutide, midazolam

Adverse events: abdominal pain, headache, phototoxicity, hives, rashes, liver toxicity, lupus-like syndrome and acute intermittent porphyria. Lichenoid eruption, pityriasis rosea, subungual hemorrhage, porphyria cutanea tarda may occur.

Drug Interactions: Barbiturates decrease the plasma levels of griseofulvin, griseofulvin diminish the effect of oral anticoagulants (coumarin) and perhaps of contraceptives.

\section{SELENIUM SULFIDE}

Indication: treatment of pityriasis versicolor ${ }^{1-3,31-14,16}$ Presentation: $2-5 \%$ Shampoo

Dosage: Use once a day for 7 days and then on the first and third days of the week for 6 months. ${ }^{1}$

Adverse Events: dermatitis, erythema dyschromicum perstans, photosensitivity, pruritus, alopecia, and brittle hair.

\section{NEW ANTIFUNGAL DRUGS}

In recent years, due to the appearance of fungi resistant to conventional treatment, much effort has been directed toward the development of more effective antifungal therapy. ${ }^{27-43}$

\section{RILOPIROX}

This is a synthetic pyridone derivative used for topical treatments. Rilopirox is a fungicide with good activity against Candida albicans and for which it can be applied vaginally. No adverse events were described. Recent studies also suggest a role in pityri- asis versicolor, seborrheic dermatitis and oropharyngeal candidiasis.

\section{LANOCONAZOLE or NND 3138}

It is a topical imidazole used for treating mucocutaneous candidiasis and dermatophytosis (especially tinea pedis and corporis) that inhibits the formation of ergosterol and thereby fungal growth. It can trigger allergic contact dermatitis, however cross-reactivity with other imidazole derivatives has not been reported.

\section{NND 502}

It is a lanoconazole analogue for topical use, effective against dermatophytes (especially T. rubrum and T. mentagrophytes).

\section{BUTENAFINE}

This is the first member of a new class of antifungal benzylamine derivatives used topically in the treatment of dermatophytosis (tinea pedis, tinea cruris, and tinea corporis). Eventually, adverse events such as, burning or stinging may occur.

Butenafine hydrochloride is a benzylamine derivative with a mechanism of action similar to that of terbinafine and naftifine. Its spectrum of antifungal activity and indications are also similar to those of allylamines.

\section{EBERCONAZOLE}

It is an imidazole derivative used topically in the treatment of resistant Candida (Candida crusei and Candida glabrata) and dermatophytosis. Adverse events such as erythema, itching and burning may occur.

\section{VORICONAZOLE}

This new oral / parenteral triazole is used to treat infections caused by Candida and Aspergillus. Adverse events reported include transient visual disturbances and dose-dependent disorders like blurred vision, elevated transaminases, discoid lupus and photosensitivity.

Category D in pregnancy.

Drug interactions: astemizole, atazanavir, barbiturates, carbamazepine, clopidogrel, diclofenac, lopinavir, omeprazole, rifampin, ritonavir.

Adverse events: anaphylaxis / anaphylactoid reactions, erythema multiforme, graft-versus-host reaction, drug-induced lupus erythematosus, photosensitivity, phototoxicity, Stevens-Johnson syndrome, alopecia, gingival hyperplasia, cardiovascular, central nervous system, neuromuscular, gastrointestinal and respiratory symptoms. 


\section{REFERENCES}

1. Verma S, Heffernan MP. Superficial fungal infection: dermatophytosis, tinea nigra, piedra. In: Fitzpatrick TB, Eisen AZ, Wolff K, Freedberg IM, Austen KF, editors. Dermatology in general medicine. 7th ed. New York: McGraw-Hill; 2008. p. 1807-21.

2. Hay RJ, Ashbee HR. Superficial mycoses. In: Burns T, Breathnach S, Cox N, Griffiths C, editors. Rook's Textbook of Dermatology. 8th ed. New Jersey: Wiley Blackwell; 2010. p. 36.5-36.68.

3. Sobera JO, Elewski BE. Fungal diseases. In: Bolognia JL, Jorizzo JL, Rapini RP, editors. Dermatology. 2nd ed. New York: Mosby Elsevier; 2008. p. 1135-49.

4. Croxtall JD, Plosker GL. Sertaconazole: a review of its use in the management of superficial mycoses in dermatology and gynecology. Drugs. 2009;69:339-59.

5. Lacaz CS, Porto E, Martins JEC, Heins-Vaccari EM, Melo NT. Tratado de Micologia Médica (Medical Mycology Treaty). Lacaz. 9. ed. São Paulo: Sarvier; 2002. p. 252340.

6. Gupta AK, Cooper EA. Update in antifungal therapy of dermatophytosis. Mycopathologia. 2008;166:353-67.

7. Murray PR, Kobayashi GS, Pfaller MA, Rosenthal KS. Superficial, cutaneous and subcutaneous mycosis. In: Murray PR, Kobayashi GS, Pfaller MA, Rosenthal KS. Microbiology medical. 2nd ed. St. Louis: Mosby; 1994. p. 404-437.

8. Rand S. Overview: the treatment of dermatophytosis. J Am Acad Dermatol. 2000;43:S104-12.

9. Lesher JL Jr. Oral therapy of common superficial fungal infection of the skin. J Am Acad Dermatol. 1999;40:S31-4.

10. Hardman JG, Limbird LE, Gilman AG. Agentes Antifúngicos (Antifungal Agents). In: Hardman JG, Limbird LE, Gilman AG. Goodman \& Gilman: as bases farmacológicas da terapêutica (Goodman and Gilman's: the pharmacological basis of therapeutics). 10. ed. Rio de Janeiro: Mc Graw Hill; 2003.

11. Zhang AY, Camp WL, Elewski BE. Advances in topical and systemic antifungals. Dermatol Clin. 2007;25:165-83, vi.

12. Azulay RD, Azulay DR, Abulafia LA. Micoses superficiais (Superficial Mycoses). In: Azulay DR. Dermatologia (Dermatology). 5. ed. Rio de Janeiro: Guanabara Koogan; 2011. p. 419-39.

13. Litt JZ. Drug eruptions \& reactions manual: D.E.R.M. 18th ed. New York: Informa Healthcare; 2012

14. Roberts DT. Onychomycosis: current treatment and future challenges. $\mathrm{Br} \mathrm{J}$ Dermatol. 1999;141:1-4

15. Lurati M, Baudraz-Rosselet F, Vernez M, Spring P, Bontems 0 , Fratti M, et al. Efficacious treatment of non-dermatophyte mould onychomycosis with topical amphotericin B. Dermatology. 2011;223:289-92.

16. Ramos-e-Silva M, Castro MCR. Micoses superficiais (Superficial Mycoses). In: Ramos-e-Silva M, Castro MCR. Fundamentos de Dermatologia (Fundaments of Dermatology). ed. rev. atual. Rio de Janeiro: Atheneu, 2010. p. 879-97.

17. Charles AJ. Superficial cutaneous fungal infections in tropical countries. Dermatol Ther. 2009;22:550-9.

18. Ananda-Rajah MR, Grigg A, Slavin MA. Making sense of posaconazole therapeutic drug monitoring: a practical approach. Curr Opin Infect Dis. 2012;25:605-11.

19. Pasqualotto AC, Thiele KO, Goldani LZ. Novel triazole antifungal drugs: focus on isavuconazole, ravuconazole and albaconazole. Curr Opin Investig Drugs. 2010;11:165-74.

20. Gupta AK, Kohli Y. In vitro susceptibility testing of ciclopirox, terbinafine, ketoconazole and itraconazole against dermatophytes and nondermatophytes, and in vitro evaluation of combination antifungal activity. Br J Dermatol. 2003;149:296-305.

21. Morales-Molina JA, Fayet-Pérez A, Martínez-Plata E, Pérez-Moyano R, MolinaArrebola MA. Interaction between amorolfine and acenocoumarol. Eur J Clin Pharmacol. 2012;68:1687-8.

22. Chen SC, Sorrell TC. Antifungal agents. Med J Aust. 2007;187:404-9.

23. Cetinkaya Z, Kiraz N, Karaca S, Kulac M, Ciftci IH, Aktepe OC, et al. Antifungal susceptibilities of dermatophytic agents isolated from clinical specimens. Eur $\mathrm{J}$ Dermatol. 2005;15:258-61.

24. Lecha M, Effendy I, Feuilhade de Chauvin M, Di Chiacchio N, Baran R; Taskforce on Onychomycosis Education. Treatment options - development of consensus guideline. J Eur Acad Dermatol Venereol. 2005;19:25-33.

25. Gupta AK, Katz HI, Shear NH. Drug interactions with itraconazole, fluconazole, and terbinafine and their management. J Am Acad Dermatol. 1999;41:237-49.

26. Squire RA, Goode K. A randomised, single-blind, single-centre clinical trial to evaluate comparative clinical efficacy of shampoos containing ciclopirox olamine (1.5\%) and salicylic acid $(3 \%)$, or ketoconazole $(2 \%$, Nizoral) for the treatment of dandruff/seborrhoeic dermatitis. J Dermatolog Treat. 2002;13:51-60.
27. Rubin Al, Bagheri B, Scher RK. Six novel antimycotics. Am J Clin Dermatol. 2002;3:71-81.

28. Brasch J. New aspects in the diagnosis and therapy of dermatomycoses. Hautarzt. 2012;63:390-5

29. Türel 0. Newer antifungal agents. Expert Rev Anti Infect Ther. 2011;9:325-38

30. Sigle HC, Schäfer-Korting M, Korting HC, Hube B, Niewerth M. In vitro investigations on the mode of action of the hydroxypyridone antimycotics rilopirox and piroctone on Candida albicans. Mycoses. 2006;49:159-68.

31. Korting HC, Grundmann-Kollmann M. The hydroxypyridones: a class of antimycotics of its own. Mycoses. 1997;40:243-7.

32. Nenoff $P$, Haustein UF. In vitro susceptibility testing of Malassezia furfur against rilopirox. Skin Pharmacol. 1997;10:275-80.

33. Ghannoum MA, Long L, Kim HG, Cirino AJ, Miller AR, Mallefet P. Efficacy of terbinafine compared to lanoconazole and luliconazole in the topical treatment of dermatophytosis in a guinea pig model. Med Mycol. 2010;48:491-7.

34. Ghannoum MA, Welshenbaugh A, Imamura $Y$, Isham N, Mallefet P, Yamaguchi $H$. Comparison of the in vitro activity of terbinafine and lanoconazole against dermatophytes. Mycoses. 2010;53:311-3.

35. Uchida K, Nishiyama Y, Yamaguchi H. In vitro antifungal activity of luliconazole (NND502), a novel imidazole antifungal agent. J Infect Chemother. 2004;10:216-9.

36. Soga F, Katoh N, Kishimoto S. Contact dermatitis due to lanoconazole, cetyl alcohol and diethyl sebacate in lanoconazole cream. Contact Dermatitis. 2004;50:49-50.

37. Koga H, Nanjoh Y, Makimura K, Tsuboi R. In vitro antifungal activities of luliconazole, a new topical imidazole. Med Mycol. 2009;47:640-7.

38. Uchida K, Nishiyama Y, Tanaka T, Yamaguchi H. In vitro activity of novel imidazole antifungal agent NND-502 against Malassezia species. Int J Antimicrob Agents. 2003:21:234-8.

39. Das S, Barbhuniya JN, Biswas I, Bhattacharya S, Kundu PK. Studies on comparison of the efficacy of terbinafine $1 \%$ cream and butenafine $1 \%$ cream for the treatment of Tinea cruris. Indian Dermatol Online J. 2010;1:8-9.

40. Singal A. Butenafine and superficial mycoses: current status. Expert Opin Drug Metab Toxicol. 2008;4:999-1005.

41. Moodahadu-Bangera LS, Martis J, Mittal R, Krishnankutty B, Kumar N, Bellary S, et al. Eberconazole--pharmacological and clinical review. Indian J Dermatol Venereol Leprol. 2012;78:217-22.

42. Repiso Montero T, López S, Rodríguez C, del Rio R, Badell A, Gratacós MR. Eberconazole $1 \%$ cream is an effective and safe alternative for dermatophytosis treatment: multicenter, randomized, double blind, comparative trial with miconazole $2 \%$ cream. Int J Dermatol. 2006;45:600-4.

43. Keshtkar-Jahromi M, McTighe AH, Segalman KA, Fothergill AW, Campbell WN. Unusual case of cutaneous and synovial Paecilomyces lilacinus infection of hand successfully treated with voriconazole and review of published literature. Mycopathologia. 2012;174:255-8.

\footnotetext{
MAILING ADDRESS:

Maria Fernanda Reis Gavazzoni Dias

Rua Mariz e Barros 176 salas 607 e 608

Icaraí

24220121 - Niterói -RJ

Brazil

E-mail:mgavazzoni@gmail.com
}

How to cite this article: Dias MFRG, Bernardes-Filho F, Quaresma-Santos MVP, Amorim AGF, Schechtman RC, Azulay DR. Treatment of superficial mycoses: review part II. An Bras Dermatol. 2013;88(6):937-44. 